\title{
Emerging issues and needs to focus on mental health and well-being in India: a qualitative analysis
}

\author{
Suantak Demkhosei Vaiphei, Devendra Singh Sisodia
}

Clinical Psychology Department, Bhupal Noble's University, Udaipur, India

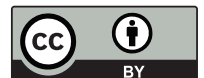

This work is licensed under a Creative Commons Attribution 4.0 International License

Received: 2019-10-08

Accepted: 2019-11-03

UDC: 616.1

J Clin Med Kaz 2019; 4(54):10-14

Corresponding Author: Suantak Demkhosei Vaiphei, $\mathrm{PhD}$ Research Scholar, Clinical Psychology, Bhupal Noble's University, Udaipur, India. Email: gdsuantak@yahoo.com
Abstract

Mental health and wellbeing of the whole are the most neglected area of care in the country leading to the highest number of teenage suicide rates. Mental illness is still considered as an illness not to be treated, resulting India becoming the most depressed country in the world, followed by China and USA as per the latest World Health Organization report. At present, 150 million Indians are suffering from mental illness and desperately in need of immediate care assessment for their mental health condition. However, $70-92 \%$ of the mental ill populations failed to receive any medical assessments, due to the minimal availability of the mental healthcare workers like psychologists and psychiatrists, which is at the ratio of 1:100,000. It would not be an exaggeration to state that India becomes the hub for global mental health epidemic. However, only 0.06 per cent of India's health budget is devoted to mental health treatment, in which the available data suggests that the state of spending the sanctioned budget in this regard is abysmal. Lack of awareness, ignorance, social stigma, and discriminations becomes the underlying factors for worsening the individual mental health conditions. Thus, the need of the hour is the immediate mental healthcare intervention, awareness about the issue, availability of the professional help and forming the adequate policies on mental health assessment. It is through timely assessment intervention a positive outcome that is meaningful for the people and for many sectors of the society can be delivered.

Key words: mental health, well-being, depression, anxiety, stress

\section{ҮНДІСТАНДАҒЫ ПСИХИКАЛЫҚ ДЕНСАУЛЫҚ ПЕН ӘЛ-АУҚАТҚА ЕРЕКШЕ НАЗАР АУДАРУДЫ ҚАЖЕТ ЕТЕТІН ӨЗЕКТІ МӘСЕЛЕЛЕР: САПАЛЫ ТАЛДАУ С.Д. Вайпей, Д.С. Сисодиа}

Клиникалық психология кафедрасы, Бупал Нобелс Университеті, Удайпур, Үндістан

\section{ТҰЖЫРЫМДАМА}

Психикалық денсаулық және жалпы әл-ауқат елдегі медициналық көмектің елеусіз саласы болып табылады, бұл жасөспірімдер арасындағы суицидтің жоғары деңгейіне әкеледі. Психикалық ауру әлі де емделмейтін ауру болып саналады, бұл Дүниежүзілік денсаулық сақтау ұйымының соңғы есебіне сәйкес Үндістанды әлемдегі ең депрессиялық елге айналдырады, одан кейін Қытай мен АҚШ келеді. Қазіргі уақытта 150 миллион үнділік психикалық аурудан зардап шегеді және өздерінің психикалық денсаулығының жай-күйін бағалауға аса мұқтаж.

Алайда, психикалық ауытқулары бар халықтың 70-92\%-ы психологтар мен психиатрлар сияқты медициналық қызметкерлердің тапшылығына байланысты медициналық тексерістен өте алмады, олардың қатынасы 1: 100000 құрайды. Үндістан жаһандық психикалық індет орталығына айналуда деп айту артық емес. Алайда, Үндістан денсаулық сақтау бюджетінің тек 0,06\% -ы психикалық денсаулықты сақтауға арналған. Бірақ қолда бар деректер бекітілген бюджеттің шығындалу жағдайы өте нашар екенін көрсетеді.

Жеткілікті түрдегі хабарсыздық, білімсіздік, әлеуметтік стигматизация және кемсітушілік адамның психикалық денсаулығының нашарлауының негізгі факторларына айналуда. Осылайша, психиатриялық көмекке жедел араласу, проблеманы білу, кәсіби көмекке қол жетімділік және психикалық денсаулықты бағалаудың тиісті саясатын әзірлеу өте маңызды. Уақытылы бағалаудың арқасында оң нәтижеге қол жеткізуге болады, бұл адамдар мен қоғамның көптеген топтары үшін маңызды.

Негізгі сөздер: психикалық денсаулық, әл-ауқат, депрессия, алаңдаушылық, күйзеліс 
АКТУАЛЬНЫЕ ВОПРОСЫ, ТРЕБУЮЩИЕ ОСОБОГО ВНИМАНИЯ КАСАТЕЛЬНО ПСИХИЧЕСКОГО ЗДОРОВЬЯ И БЛАГОПОЛУЧИЯ В ИНДИИ: КАЧЕСТВЕННЫЙ АНАЛИЗ

С.Д. Вайпей, Д.С. Сисодиа

Кафедра клинической психологии, Университет Бупал Нобелс, Удайпур, Индия

\section{PEЗЮME}

Психическое здоровье и благополучие в целом является наиболее обделенной вниманием областью медицинской помощи в стране, что приводит к наивысшему уровню самоубийств среди подростков. Психическое заболевание по-прежнему считается болезнью, которую не лечат, в результате чего Индия становится самой депрессивной страной в мире, за ней следуют Китай и США согласно последнему докладу Всемирной организации здравоохранения. В настоящее время 150 миллионов индусов страдают психическими заболеваниями и остро нуждаются в немедленной оценке состояния психического здоровья. Однако $70-92 \%$ населения с психическими расстройствами не смогли пройти какое-либо медицинское обследование в связи с нехваткой таких медицинских работников, как психологи и психиатры, соотношение которых составляет 1:100 000. Не будет преувеличением отметить, что Индия становится центром глобальной эпидемии психического здоровья. Тем не менее, всего лишь 0,06\% бюджета здравоохранения Индии направлено на лечение психического здоровья. Но имеющиеся данные свидетельствуют о том, что состояние расходования утвержденного бюджета в этом отношении является плачевным. Недостаточная осведомленность, невежество, социальная стигматизация и дискриминация становятся основными факторами ухудшения состояния психического здоровья человека. Таким образом, немедленное вмешательство в психиатрическую помощь, осведомленность о проблеме, доступность профессиональной помощи и формирование адекватной политики по оценке психического здоровья являются насущной необходимостью. Именно благодаря своевременному оценочному вмешательству может быть достигнут положительный результат, значимый для людей и для многих слоев общества.

Ключевые слова: психическое здоровье, благополучие, депрессия, беспокойство, стресс

\section{Introduction}

"Mental pain is less dramatic than physical pain, but it is more common and also harder to bear"

\section{- C.S Lewis.}

Mental health is a worldwide phenomenon that needs special attention and cares for every individual at any stage of life, from very young age to the adulthood. Mental health problem is a common issue to every individual daily life, relationship, and physical health regardless of their age. Mental health includes human emotional, psychological, behavior, and social wellbeing as it determine on how one deals with stress, think and make choices. Looking at the current situation of India the progress in regards to the mental health services are visible minimal, mainly due to the unavailability of trained mental healthcare professionals. According to the WHO "health is a state of complete physical, mental, and social wellbeing, not only the absence of disease or infirmity." It is a state of wellbeing whereby individuals recognize their abilities, are able to cope with the normal stresses of life, work productively and make an enormous contribution to the society or communities. In which, mental health is about enhancing the competencies of individuals and communities and enabling them to achieve their self-determined goals in the most effective ways [1]. However, mental health is an unconcern area of care in India leading to higher suicide rate among the youths in the global death rate. Thus, the current study has been form to investigate the underlying reason on why mental health is the least concern in India. The aim is also to find out traditional solutions, create awareness, and to form adequate policy on mental health assessment for the better India tomorrow.

\section{Objective}

The study is formed with an aim to highlight the importance of the mental health assessment in Indian healthcare system to deliver quality of life in Indian clinical practices.

\section{Methods}

It is a collective review of the existing documents and literatures on the importance of mental health assessment in clinical diagnosis with the propose solutions. The study also focuses on the barriers to mental health and well-being in the country.

\section{Mental health: the present scenario}

Mental health is not merely the absence of disease or infirmity; it rather is a state of complete physical, mental, and social wellbeing. The concepts of mental health includes subjective wellbeing, perceived self-efficacy, autonomy, competence, intergenerational dependency and recognition of the ability to realize one's intellectual and emotional potential. Mental health refers to the person emotional and psychological wellbeing that relatively helps to demonstrate resilience and the ability to cope in the face of any life's adversities [1]. Mental health can be sometime influenced by several factors like life events, genetics, environment, daily habits, and biological process. It is common to every stages of life and at some point it leads to suicidal activities. Some of the common mental illness that frequently affected people are: Bipolar Disorder, Panic Disorder, Persistent Depressive Disorder, General Anxiety Disorder (GAD), Major Depressive Disorder (MDD), Obsessive-Compulsive Disorder (CD), Post-Traumatic Stress Disorder (PTSD), Schizophrenia, and Social Anxiety Disorder The term mental health is sometimes used to denote the human condition, which is free from any kinds of mental disorder; having cognitive, behavioral wellbeing, social maturity, and appropriate balance of love, work, and leisure pursuits [2]. In a recent National Mental Health survey around 150 million Indians are suffering from mental illness and desperately in need of immediate care assessment for their mental health condition. However, around $70-92 \%$ of the mental ill populations failed to receive their treatment, as mental health and wellbeing are the most neglected area of care in the country. In the India today, mental illness is still not considered as an illness to be treated or as serious physical ailments [3]. Even in its clinical practices mental health remains as the untouched area of care that even worsen the condition of the patients and the family. Indian tends to forget that mental wellbeing is the core to quality of life and wellbeing of the whole.

Unfortunately, India becomes the most depressed country in the world, which is hugely affected by anxiety, schizophrenia, and bipolar disorder followed by China and USA as per the latest World Health Organization report. The National Care of Medical Health stated that at least 6.5 per cent of the Indian population is under serious mental disorder both in the rural and the urban areas. Unlike the other regular medical treatments, consulting the 
psychologists or the psychiatrists are considered as taboo in the Indian society, resulting in the minimal availability of the mental healthcare workers like psychologists and psychiatrists in the country. The 2014 survey reported that the ratio of psychologists and the people who need the psychological assessment are in the ratio of $1: 100,000$. The study also shows that the average suicide rate in India is 10.9 in 100,000 populations, in which majority of those Indian who committed suicide are in below 44 years of age [4]. Moreover, the WHO reported that India has the highest number of teenage suicide rates in the world. It would not be an exaggeration to state that India is the origin and hub for global mental health epidemic. However, only 0.06 per cent of India's health budget is devoted to mental health treatment, in which the available data suggests that the state of spending the sanctioned budget in this regard is abysmal. Looking at the current situation, majority of the Indian facing mental health issues are mainly due to lack of awareness, ignorance and blatant apathy, leading to a vicious cycle of shame, suffering and patient isolating themselves from the crowd. Thus, the need of the hour is the immediate mental healthcare intervention, awareness about the issue, availability of the professional help and forming the adequate policies on mental health assessment [5]. It is trough timely assessment intervention a positive outcome that is meaningful for the people and for many sectors of the society can be delivered.

\section{Causes and symptoms of mental disorders}

Mental health issues are mainly through several genetic and environment factors (biological factor). Mental health disorders are found common through inheriting process from the blood relatives who have suffered from the mental illness (family history). Certain genes increase the risk developing a mental illness, depending on one's life situation may trigger it like abuse or trauma (life experiences). While, some mental health issue arises through the parent environmental exposures resulted in the child mental disorder. The exposure to environmental stressors, inflammatory conditions, toxins, alcohol, drugs while in the womb can sometime makes the child suffering from mental illness. Brain chemistry is also another cause for mental health problem; when the neurotransmitters that carry signals from one part to the other parts of the brain and body impaired, the function of nerve receptors and nerve systems change dramatically leading to depression and other emotional disorders [6]. Moreover, concerning the global burden around $16 \%$ mental health issues are mainly due to disease and injury ranging in the age of 10-19 years, in which half of all the mental health conditions begins at the age of 14 years and unfortunately most cases are undetected and left untreated. On the other hand, depression is considered as the leading cause of mental illness and disability among adolescents. Failing in addressing adolescent mental health conditions extend to adulthood resulting in impairing both physical and mental health that affected to live an adulthood life to the fullest [4]. In a developing country like India the underlying factors for the mental illness are: financial hardship, lack of healthcare, lack of education/skill, lack of basic resources, inability to provide for self and for one's family, and unfulfilled desires in life leading to suicide among the poor and underprivileged people. Daily life experience such as trauma, abuse, smoking, drinking, economic crisis and discrimination also plays an important role in causing mental illness in India[3].

Looking at the current condition of India as a whole, mental illness is visible causing life miserable and severe problems in daily life and relationships. The signs and symptoms of mental disorder can be varying from one person to another depending on the types of disorder one has gone through. In general mental health symptoms can affects emotions, thoughts and behaviors. The followings are some of the early signs and the common mental health symptoms:

Table 1 Signs and symptoms of mental health disorders

\begin{tabular}{|c|c|c|}
\hline \multicolumn{2}{|c|}{ SIGNS AND SYMPTOMS OF MENTAL ILLNESS } \\
\hline Excessive Use Of Drugs & Withdrawing From People And Usual Activities & Consistently Having Low Or No Energy \\
\hline Sleeping Or Eating Too Much Or Too Little & Feeling Numb Or Like Nothing Matters & $\begin{array}{c}\text { Displaying Uncharacteristic Emotion And } \\
\text { Confusion }\end{array}$ \\
\hline Not Being Able To Complete Standard Tasks & $\begin{array}{c}\text { Persisting Thoughts Or Memories That Reappear } \\
\text { Regularly }\end{array}$ & \begin{tabular}{c} 
Thinking Of Harming One's Self Or Others \\
\hline Hearing Voices, Delusion
\end{tabular} \\
\hline Experiencing Severe Mood Swing & Having Unexplained Aches And Pains & Feeling Helpless Or Hopeless \\
\hline Traumatic Experience & Stressful Life Situations & Inability to Perform Daily Task \\
\hline
\end{tabular}

It is not always possible in most cases to identify whether someone is developing any types of mental health problem. However, if the above symptoms and signs are being developed in a short space of time, it may lead to the clue that the person is facing a mental health issue. It is also important to identify what types of treatment can work in the individual as each mental issue has their own strategies or treatments. Some of the underlying treatments around the mental health are Psychotherapy that includes CBT-Cognitive behavior therapy, exposure therapy, and dialectical behavior therapy; Medication for symptoms improvement; Self-help including lifestyle changes like reducing drug intake, sleeping more, and eating well [7]. Most importantly, getting professional help in the initial process of mental health is the core to have a positive mental health, which will lead individual to cope successfully with stressful life events.

\section{Barriers to current mental health services}

Mental health is an integral part of health and can be affected by a range of psychosocial-economic factors that need comprehensive strategically approach for promotion, prevention, treatment, and recovery. In a low- and middle-income country like India, the advance progress in mental health service is visible consistently slow and minimal. Some of the major barriers can be seen in the existing public health priorities and its influence on funding; challenges to delivery of basic mental health care in the primary care settings; the minimal numbers of well-trained professionals in the area of mental healthcare; 
and lack of mental health perspective in public-health leadership [8]. The existing barriers are mainly due to the lack of funding for mental health services is the core barrier in implementing quality mental health services, including inadequate coordinated and consensus based national mental health advocacy and plans, the absence of mental health in major donor priorities, marketing of expensive pharmaceuticals by industry, cost-effectiveness information on mental health services that is unknown to senior decision-makers and social stigma among others [9]. Moreover, lack of strong mental health advocacy in countries to increase resources for mental health services and the role of social stigma and the view that mental health is a private responsibility are also the two barriers to mental health.

In India at present, social stigma and discrimination against people with mental disorders is an underlying barrier to mental health service. It contributes to delays in seeking care, impedes timely diagnosis and treatment for mental disorders, serves as an impediment to recovery and rehabilitation, and ultimately reduces the opportunity for fuller participation in life [10]. In recent investigations, the major barriers to mental health service utilization include a scarcity of resources, unequal distribution, inefficient use, non-medical explanations, and a lack of awareness, and accessibility. Among all, one of the major problems that exist in Indian mental healthcare is the treatment gap, or the number of individuals with an illness who need treatment but do not receive it [11]. The studies also highlighted the shortage of mental health resources, inadequate infrastructures, and the scarcity of healthcare professionals as the underlying barriers that contributed in failing to provide quality mental healthcare in India. The five key barriers that need to be overcome to the address the prevailing challenges of mental health issues in the country are [12]:

- Anti-Social Disorder (Overreacting to a particular situation with anger and behave in a way that is harmful to others);

- Amnesia (Experiencing persistence loss of memory);

- Asperger's Syndrome (Difficulty and reluctance towards social interaction, verbal communication, physical clumsiness and repetitive pattern of behavior);

- Major Depressive Disorder (Low self-esteem, reluctance towards enjoyable activities, high pessimism, avoiding social gathering, and morbid thoughts);

- Obsessive-Compulsive Disorder-OCD (mental disorder where the victim feels a constant need to set things/objects right, and repeating a particular chore).

Overcoming the above listed barriers can help individual in combating the social stigma of the modern Indian society and suicidal activities in the most successful ways. It will also help in tackling down the anxiety disorder, stress, depression, and will pave a way to have quality time with others and in building quality relationships.

\section{Propose solutions and suggestions}

Looking at the current condition of mental health in India, it is a high time to bring it into the light from being hidden under the curtain of social stigma and discriminations. It is clear that 150 million people in India need immediate mental health assessment, while the 70 to 92 percent of these populations failed to receive mental treatment, as mental health and wellbeing being one of the most neglected area of care in the country. At this point, the needs of the hour in India is mainly to focus on the preventive measures and the treatment plans and policies like, accepting mental health problem as a serious illness to be treated like the other physical symptoms; increasing public knowledge and awareness of mental disorders; to train maximum number of mental health professionals; to standardized the structured of mental ill diagnosis and with psychopharma interventions; maximizing the numbers of quality rehabilitation centers for people suffering from substance abuse; more mental health hospitals for the psychiatric patients with quality care and treatment options available for mental disorders; implementing mental health First Aid Officers in communities, schools, colleges, and in organizational levels. It is also important to contextualize the Indian sub-culture with the latest therapeutic techniques, temperaments, and cognitive biases needs to encounter the prevailing challenges of mental health disorders in the country [3].

The focuses on holistic education by introducing 'Happiness Curriculum' in the school syllabus by the Delhi Govt. and the 'Happiness' program launched by the IIT Madras that includes meditation, value education, and mental exercise served as an innovative step towards building a quality mental health and wellbeing in the society. It is the absence of value based curriculum in schools and at home has created a vacuum in today's children mindset, not knowing on how to feel content and happy [13]. The absence of anti-anxiety medications, antipsychotic medications, and mood-stabilizing medications in the Indian mental health disorder treatments are also the major factors that turn India into a mental disorder hub. It is to be noted that mental illness is the leading cause of disability; it can also worsen emotional, behavior, and physical problems of the individual. Some of the traditional ways to combat with the mental health disorders in India can include developing positive attitude towards self and others; regular exercise to stay physically active; voluntary works on helping others; getting enough sleep; eating healthy diet; being socialized and spending time with others; and the most importantly, seeking professional help and using effective coping skills to deal with problems or issues in life. Finding purpose and meaning in life that can benefit others and self is also an effective mechanism to overcome mental health problems. Developing positive mental health is the core to make life more meaningful and to cope with stresses of life.

\section{Conclusion}

Mental health wellbeing is a positive outcome that creates a quality of life and living for people and the society, however it is an unheard topic in many developing countries. The underlying reason behind India turning into a mental health disorder hub could be the lack of awareness, social stigma, and discriminations. The only way to overcome the prevailing social stigma on mental health is to spread awareness on the causes, effects, and the quality steps to be taken on its diagnosis. Improving medical and mental health related technologies and making it available at any cost in its mental health centers could also be another solution. Increasing the numbers of mental health centers with quality treatment is the need of the hour in India. It is also important to implement mental health and its seriousness as a subject of study in the high schools and college's level would enhance people awareness on the importance of mental health and wellbeing in the society.

Disclosures: There is no conflict of interest for all authors. 


\section{References}

1. World Health Organization. Investing in Mental Health. Geneva: World Health Organization, 2003.

2. Holland, Kimberly. Mental Health Basics: Types of Mental Illness, Diagnosis, Treatment. http://www.healthline.com/2018/ health/mental-health

3. Sanyal, Vihan. Why India Needs to Focus on Mental Health and Wellbeing. http://yourstory.com/2018/10/india-needs-focusmental-health-wellbeing

4. India Today. India is the Most Depressed Country in the World. https:/www.indiatoday.in/education-today/gk-current-affairs/ story/india-is-the-most-depressed-country-in-the-world-mental-health-day-2018-1360096-2018-10-10

5. Khajuria, Akansha (2019). Mental Health Crisis in India: It's Now or Never. https://www.youthkiawaaz.com/2019/01/the-issueof-mental-health-in-india/

6. Mayo Clinic (2019). Mental Illness. http://www.mayoclinic.org/disease-conditions/mental-illness/symptoms-causes/syc20374968

7. Legg, Timothy L. What is Mental? and Causes. http://www.medicalnewstoday.com/articles/154543.php

8. Srivastava, Kalpana. Chatterjee, Kaushik. \& Shivaram Bhat Pookala. Mental Health Awareness: The Indian Scenario. Indian Psychiatry Journal. 2016; 25(20):131-134. https://doi.org/10.4103/ipj.ipj_45_17

9. World Health Organization. Expert Opinion on Barriers and Facilitating; Factors for the Implementation of Existing Mental Health Knowledge in Mental Health Services. https://www.who.int/mental_health/emergencies/expert_opinion_on_service_ development_msd_2007.pdf

10. Shidhaye, Rahul \& Kermode, Michelle. Stigma and Discrimination As A Barrier To Mental Health Service Utilization In India. International Health Journal. 2013; 5(1):6-8. https://doi.org/10.1093/inthealth/ihs011

11. Kaur, Reetinder \& Pathak, R K. Treatment Gap in Mental Healthcare: Reflections from Policy and Research. Economic and Political Weekly. 2017; 52:31. https://www.epw.in/journal/2017/31/perspectives/treatment-gap-mentalhealthcare.html

12. IndiaToday. 5 Barriers To Addressing Mental Health Issues, Facts You Should Know, Common Mental Disorders Worldwide. https://www.indiatoday.in/education-today/gk-current-affairs/story/5-barriers-mental-health-issues-facts-common-mentaldisorders-345797-2016-10-10

13. Mehta, Madhuri. Here's how the 'Happiness Curriculum' in Delhi Govt. Schools can Build a Healthy Mind. https://www. indiatoday.in/education-today/news/story/here-s-how-happiness-curriculum-in-delhi-govt-schools-can-build-a-healthymind-1311804-2018-08-11

How to cite this article: Suantak Demkhosei Vaiphei, Devendra Singh Sisodia. Emerging issues and needs to focus on mental health and well-being in India: a qualitative analysis. J Clin Med Kaz. 2019; 4(54):10-14 